Article

\title{
Review of Ecosystem Level Impacts of Emerald Ash Borer on Black Ash Wetlands: What Does the Future Hold?
}

\author{
Randall K. Kolka ${ }^{1, *}$, Anthony W. D'Amato ${ }^{2}$, Joseph W. Wagenbrenner ${ }^{3}$, Robert A. Slesak ${ }^{4}$, \\ Thomas G. Pypker ${ }^{5}$, Melissa B. Youngquist ${ }^{6}$, Alexis R. Grinde ${ }^{7}$ and Brian J. Palik ${ }^{1}$ \\ 1 USDA Forest Service Northern Research Station, Grand Rapids, MN 55744, USA; bpalik@fs.fed.us \\ 2 Rubenstein School of Environment and Natural Resources, University of Vermont, \\ Burlington, VT 05405, USA; awdamato@uvm.edu \\ 3 USDA Forest Service Pacific Southwest Research Station, Arcata, CA 95521, USA; jwagenbrenner@fs.fed.us \\ 4 Minnesota Forest Resources Council, St. Paul, MN 55108, USA; raslesak@umn.edu \\ 5 Thompson Rivers University, Kamloops, BC V2C 0C8, Canada; tpypker@tru.ca \\ 6 Department of Forest Resources, University of Minnesota, St. Paul, MN 55108, USA; myoungqu@umn.edu \\ 7 Natural Resources Research Institute, University of Minnesota Duluth, Duluth, MN 55811, USA; \\ agrinde@d.umn.edu \\ * Correspondence: rkolka@fs.fed.us; Tel.: +218-326-7115
}

Received: 5 March 2018; Accepted: 29 March 2018; Published: 2 April 2018

\begin{abstract}
The emerald ash borer (EAB) is rapidly spreading throughout eastern North America and devastating ecosystems where ash is a component tree. This rapid and sustained loss of ash trees has already resulted in ecological impacts on both terrestrial and aquatic ecosystems and is projected to be even more severe as EAB invades black ash-dominated wetlands of the western Great Lakes region. Using two companion studies that are simulating short- and long-term EAB infestations and what is known from the literature, we synthesize our current limited understanding and predict anticipated future impacts of EAB on black ash wetlands. A key response to the die-back of mature black ash will be higher water tables and the potential for flooding and resulting changes to both the vegetation and animal communities. Although seedling planting studies have shown some possible replacement species, little is known about how the removal of black ash from the canopy will affect non-ash species growth and regeneration. Because black ash litter is relatively high in nitrogen, it is expected that there will be important changes in nutrient and carbon cycling and subsequent rates of productivity and decomposition. Changes in hydrology and nutrient and carbon cycling will have cascading effects on the biological community which have been scarcely studied. Research to address these important gaps is currently underway and should lead to alternatives to mitigate the effects of EAB on black ash wetland forests and develop management options pre- and post-EAB invasion.
\end{abstract}

Keywords: review; hydrology; carbon; nutrients; wildlife; soil

\section{Introduction}

The emerald ash borer (EAB; Agrilus planipennis Fairmaire) is poised to decimate ash forests throughout the Great Lakes states, threatening the future of the black ash (Fraxinus nigra Marsh)-dominated wetland forests that occur throughout the region. Female EAB lay eggs in crevices of the black ash bark. The eggs hatch in about 2 weeks and the larvae feed on the inner phloem, cambium, and outer xylem for one to two years, girdling and subsequently killing the tree [1]. The geographic distribution of black ash includes the northeastern U.S. and the western Great Lakes (Figure 1), but the majority of black ash wetlands cover large portions of Michigan $(238,000 \mathrm{ha})$, Wisconsin 
(350,000 ha), and Minnesota (430,000 ha). These three states have an estimated 2.1 billion ash trees that are susceptible to EAB [2].

Black ash wetland ecosystems are an integral part of the landscape that are generally formed on poorly drained, relatively nutrient rich soils with high water tables. Soils can either be wet mineral soils or organic soils. Water tables are generally drawn down over the growing season and rebound in autumn following leaf fall. Water table elevation is an important control on black ash growth and mortality. Palik et al. [3,4] postulated that spring droughts, excessive moisture, and hydrological alterations by roads contributed to black ash crown dieback. Black ash generally dominate the canopy of these wetlands and ash density can range from approximately $40 \%$ to almost $100 \%$. Other co-dominant trees tend to be northern white cedar (Thuja occidentalis L.), red maple (Acer rubrum L.), and American elm (Ulmus americana L.) —all trees that can normally survive in inundated conditions but do not thrive as well as black ash because of physiological adaptations or pathogenic constraints (e.g., Dutch elm disease).

Hydrology is the dominant factor that influences a host of ecosystem functions in black ash wetlands. Common hydrogeomorphic settings for black ash wetlands include expansive wetland complexes with perched water tables, swales associated with drainage of small catchments, central depressional areas with drainage from surrounding uplands, and linear transitional areas that form between uplands and peatlands [5]. Source inputs are predominantly from precipitation, either directly [6] or from adjacent upland drainage [7]. In most settings, water tables are typically above the surface throughout early spring, followed by drawdown below the surface during the growing season with periodic rises following rain events. Water table drawdown coincides with peak evapotranspiration following black ash leaf out $[7,8]$, highlighting the fundamental control that this species has on animal and other plant communities.

There have been relatively few studies focused on the impacts of EAB on black ash ecosystems, largely because the spread of this invasive insect has yet to reach the large concentrations of black ash forests in the western Great Lakes region. Black ash has been shown to have similar susceptibility as green ash (Fraxinus pennsylvanica Marsh.) and white ash (Fraxinus americana L.) to EAB [9]. The discovery of EAB in St. Paul, Minnesota, in 2009, a location $100 \mathrm{~km}$ south of the largest concentration of black ash forests in the US, led to the establishment of a large-scale, manipulative study in north-central MN on the Chippewa National Forest focused on anticipating the impacts of EAB on black ash wetlands. This work utilized girdling treatments to simulate EAB impacts and also included an evaluation of adaptive management strategies to increase the resilience of black ash forests to $E A B$, such as planting non-host species as part of even-aged (clearcutting) and uneven-aged (group selection) silvicultural systems [10]. In 2010, a companion study building off this work was established in the western Upper Peninsula of Michigan on the Ottawa National Forest where the girdling treatment, a clearcut treatment, and some of the same measurements were conducted.

The form and size of black ash wetlands differ in the two locations. In Minnesota, the wetlands form in extensive areas of inundation, typically covering 10 to 150 ha, whereas in Michigan the wetlands are on the order of 1 to 2 ha that occur in depressional areas formed by glaciation. Both studies included a girdling treatment to simulate the short-term impact of EAB and a felling or harvesting treatment. The harvesting treatments in the Chippewa National Forest Minnesota study were designed to include operational harvests as part of adaptive management strategies. The Ottawa National Forest Michigan study included a harvest treatment in which all ash were felled and left in place (ash-cut) to simulate longer-term impacts of EAB infestation. In addition, the smaller size of the wetlands in the Michigan study enabled the use of a paired watershed experiment assessing the impact of the ash-cut treatment on watershed scale water flux and chemistry. 


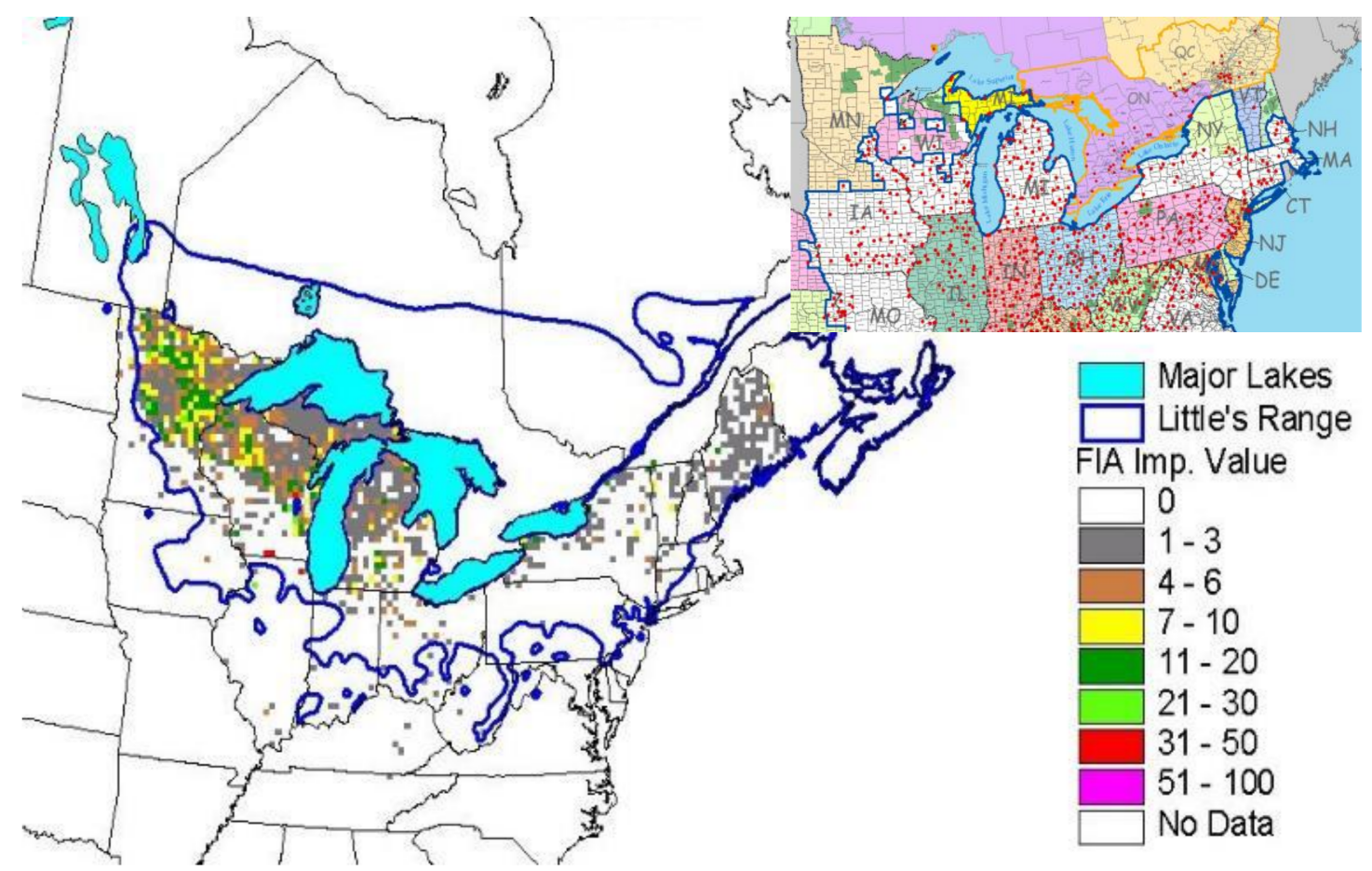

Figure 1. Geographic distribution of black ash in the United States from Forest Inventory and Analysis databases. Little's range is the geographic range of black ash based on botanical lists, forest surveys, field notes, and herbarium specimens [11]. The Forest Inventory and Analysis importance value is a measure of the abundance of a species within a stand. An importance value of 50 indicates that the stand is $50 \%$ black ash and $50 \%$ other species. Inset is the geographic distribution of emerald ash borer detected in counties as of 1 March 2018 [12].

Here, we synthesize what is known about ecosystem level impacts of EAB on black ash wetlands based, primarily, on these two study systems. Because of the adaptation of black ash to difficult growing conditions and the eradication of pole-sized and larger ash after EAB infestation, EAB impacts on black ash wetlands will likely be extreme and result in dramatic changes in hydrology and cascading effects on the plant and animal communities and nutrient cycles that influence them. Ultimately, changes in plant and animal communities will alter the carbon balance in these ecosystems. Because the structure and function of these forested wetland ecosystems rely on healthy populations of black ash, and because these systems are in imminent threat from $E A B$, understanding the potential ecosystem level consequences of EAB is necessary and timely. We focus our review on the western Great Lakes states because of the prevalence of black ash wetlands in this region. This review includes papers in this special issue of Forests and previously published studies that utilize either observations of post-invasion impacts or experimental simulation of potential impacts. We consider three major types of impacts on black ash wetland functions: (1) hydrological responses; (2) changes in nitrogen (N) and carbon (C) cycles; and (3) plant and animal responses.

\section{Hydrological Responses of Black Ash Wetlands to EAB}

Mature black ash trees can transpire up to $63 \mathrm{~L} \mathrm{day}^{-1}$ during the growing season [13]. When taking into account the area of the sapwood and the basal area of the stand, mean growing season sap flux density in Minnesota ranges from $1.6 \mathrm{~m}^{3} \mathrm{~m}^{-2}$ day $^{-1}$ in a moderately wet site to $4.6 \mathrm{~m}^{3} \mathrm{~m}^{-2}$ day $^{-1}$ in a very wet site, with vapor pressure deficit and soil moisture conditions being the main controls on sap flux [13]. Sap flux density and vapor pressure deficit were positively related when soil moisture was high (full relative saturation) but negatively related when soil moisture was low (approximately $40 \%$ of relative saturation) [13]. In contrast to the results from Minnesota, mean growing season sap flux 
density in the Michigan study was lower in the sites with highest water tables $\left(2.5 \mathrm{~m}^{3} \mathrm{~m}^{-2}\right.$ day $\left.^{-1}\right)$ as compared to the flux from the lowest water tables sites $\left(5.2 \mathrm{~m}^{3} \mathrm{~m}^{-2}\right.$ day $\left.^{-1}\right)$ [14]. Although the results seem to be conflicting, the low water table (dry) conditions in upper Michigan were comparable to the high water table (very wet) site in Minnesota. For the Minnesota sites, water table depths reached nearly $100 \mathrm{~cm}$ below the soil surface in mid-summer during the year of the study (2012), whereas at the upper Michigan sites the minimum water table over three years of study (2012-2014) was $83 \mathrm{~cm}$ below the soil surface in mid-summer. There appears to be an optimum range of water table elevations where sap flux from black ash is maximized, with that range approximately $45-100 \mathrm{~cm}$ below the soil surface. Wetlands with mean water table levels within this range may be most susceptible to hydrologic alteration and increases in hydroperiod following ash loss.

In addition to sap flux in black ash trees, Shannon et al. [14] also measured sap flux in co-dominant species of red maple and yellow birch (Betula alleghaniensis Britton). Black ash had significantly higher sap flux rates $\left(2.5-5.2 \mathrm{~m}^{3} \mathrm{~m}^{-2}\right.$ day $^{-1}$ ) than non-ash species (red maple and yellow birch ranged from $1.6-3.6 \mathrm{~m}^{3} \mathrm{~m}^{-2}$ day $\left.^{-1}\right)$ in these wetland sites at all water table levels and the difference was greatest at the lowest water table levels. The high sap flux densities in black ash coupled with low sap flux among the codominant species should lead to changes in water table dynamics after EAB invasion. For the Minnesota sites, that response was seen in the first year following clearcutting, with significantly higher water tables in the clearcut treatment than the unharvested control treatment $(\sim 20-60 \mathrm{~cm}$ higher water table elevation) (Figure 2; [8]). During the second year, the girdling impact was evident, with a similar water table response as the clearcut treatment. Interestingly, the gap harvest treatment where about $20 \%$ of the basal area was removed led to no change in the water table response relative to the unharvested control (Figure 2). The result is consistent with past studies on hydrologic responses to forest harvest which found no change in watershed output with canopy reductions less than about $20 \%$ [15].

In contrast to the Minnesota sites, the upper Michigan sites did not see a significant increase in the water table following the harvest treatment or girdling after the first two years (Figure 3; [7]). However, the two years post-treatment were abnormally wet with greater than average snowfall and rainfall, which may have masked any treatment effects. Although mean water table levels did not vary among treatments, growing seasons rates of water table drawdown were statistically higher for the unharvested control than the ash-cut or girdle treatments [7]. Differences in landscape position may have also contributed to the different effects on water table elevation, whereby subsurface inflow from surrounding uplands would have muted the effect of reduced transpiration and local water table increases following ash loss in the Michigan sites set in localized depressions. Combined, the data from both water level studies suggest that water tables will increase following EAB invasion during normal or below normal precipitation years, with slower drawdowns during the growing season.

From a water balance perspective, some of the excess water from the lower post-EAB transpiration rates $\left(\sim 0.10 \mathrm{~cm}^{\text {day }}{ }^{-1}\right.$, [7]) will likely become part of the evaporation pool or be compensated by transpiration from replacement vegetation. However, we would still expect the overall evapotranspiration to be considerably less following EAB invasion, leading to consistently higher water tables throughout the year until a tree canopy is reestablished. 


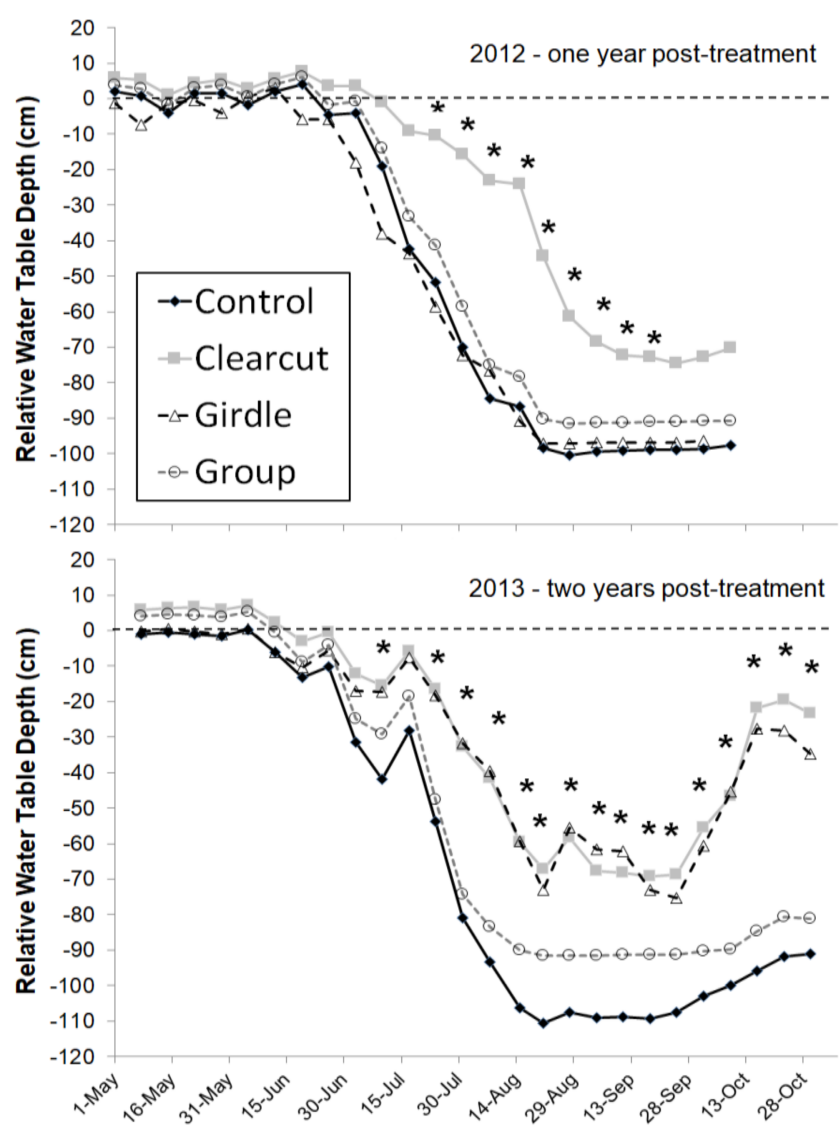

Figure 2. Weekly mean $(n=6)$ water table depth relative to ground surface by treatment from the Minnesota sites. The control treatment comprised unharvested reference sites, the clearcut treatment was a commercial harvest, trees were girdled in the girdled treatment, and group treatment was a group selection harvest creating gaps of approximately 0.04 ha. Each year's growing season was analyzed separately; weeks with an * indicate significant differences among treatments $(p<0.05)$. There were no differences among treatments prior to treatment application $(p>0.2)$ (reproduced from Slesak et al. [8]).

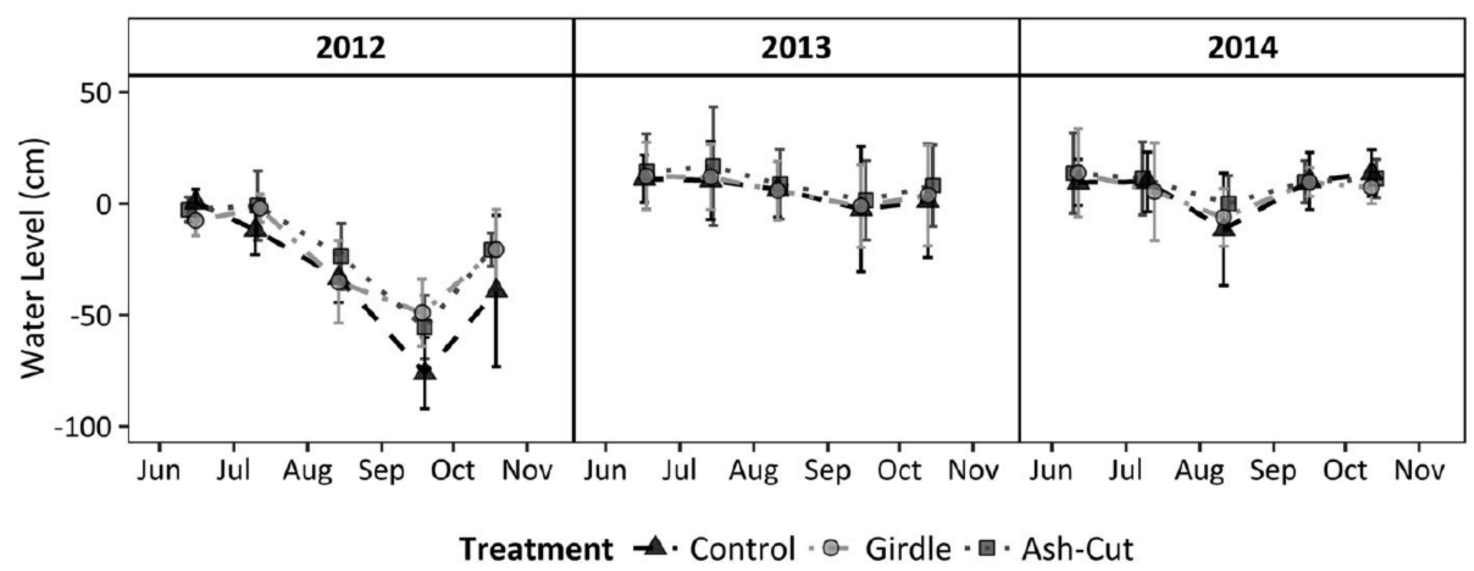

Figure 3. Mean wetland water table levels relative to the wetland soil surface, with $95 \%$ confidence intervals, during the snow-free period for the upper Michigan sites $(n=3)$. The year 2012 was the pre-treatment year and 2013-2014 were the first two post-treatment years (reprinted from Van Grinsven et al. [7]). The control treatment comprised unharvested reference sites, all ash trees were girdled in the girdle treatment, and all ash were cut and left on the ground in the ash-cut treatment. 


\section{Changes in Nitrogen (N) and Carbon (C) Cycling Resulting from EAB Invasion in Black Ash Wetlands}

Historically, there has been little research on $\mathrm{N}$ and $\mathrm{C}$ cycles in black ash wetlands. Across wetlands types, black ash wetlands tend to be relatively nutrient rich, with black ash litter having some of the highest $\mathrm{N}$, phosphorus $(\mathrm{P})$, and cation contents of any hardwood forest species $[16,17]$. At the Minnesota sites with mineral soils, $\mathrm{C}$ to $\mathrm{N}$ ratios are typically between $14-15$ at $0-30 \mathrm{~cm}$ depth, with over $75 \%$ of the total $\mathrm{N}$ found in the top $15 \mathrm{~cm}$ [18]. In the mainly organic soil sites in upper Michigan, $\mathrm{C}$ to $\mathrm{N}$ ratios were higher with a mean of 20 from $0-50 \mathrm{~cm}$ and the total $\mathrm{N}$ was relatively evenly distributed throughout the top $100 \mathrm{~cm}$ of the profile [19].

Research has been initiated to address the impacts on nutrient and C cycling in black ash wetlands. At the Michigan sites, Davis [20] found litter N concentrations in black ash to be greater than non-ash (i.e., red maple and yellow birch) species. Other studies have also found high concentrations of $\mathrm{N}$ in ash litter, leading to high turnover rates of ash litter and greater soil $\mathrm{N}$ availability compared to non-ash species [21,22]. Nisbet et al. [23] considered the reduction of ecosystem $\mathrm{N}$ following EAB invasion of ash riparian forests and speculated that (1) the terrestrial ecosystem could have dramatic changes in net primary production and species composition, and (2) lower amounts of $\mathrm{N}$ transport to streams could have cascading effects up the streams' trophic levels and lead to a lowering of stream productivity. Similarly, Palik et al. [24] found that black ash litter decomposed faster than upland derived species such as sugar maple (Acer saccharum) and trembling aspen in seasonal wetlands of northern Minnesota, suggesting loss of black ash could lead to lower quality habitat.

In upper Michigan, throughfall deposition of $\mathrm{N}$ was not influenced by girdling, but the ash-cut treatment had higher nitrate deposition than the unharvested control [20]. Preliminary soil data indicate that the ash-cut and girdled treatments had little influence on inorganic soil $\mathrm{N}$ concentrations and $\mathrm{N}$ availability [20]. Although litter and throughfall inputs of $\mathrm{N}$ are changing in the ash-cut and girdling treatments, it does not appear that enough time has passed to change soil concentrations of $\mathrm{N}$. These findings are supported by those at the Minnesota sites, where no significant treatment effects on the change in soil $\mathrm{C}$ and $\mathrm{N}$ in the upper $30 \mathrm{~cm}$ were found three years after treatment [18].

Two years following treatment, growing season soil greenhouse gas fluxes of carbon dioxide $\left(\mathrm{CO}_{2}\right)$ were significantly higher in the girdled and ash-cut treatments than the unharvested control in upper Michigan [25]. Methane $\left(\mathrm{CH}_{4}\right)$ production was higher in the ash-cut treatment than the girdled and unharvested treatments. It appears that the addition of new organic matter to the soil surface following the manipulations and potentially higher soil temperatures because of the partial canopy removal have led to at least an initial increase in decomposition, and faster rising water tables may be leading to higher efflux rates of $\mathrm{CH}_{4}$.

Preliminary data from the upper Michigan paired watershed experiment suggests that dissolved organic carbon (DOC) and dissolved organic nitrogen (DON) concentrations may increase in the first year following ash cutting [26]. Similar to increases in soil $\mathrm{CO}_{2}$ fluxes, increases in the DOC and DON concentrations are likely the result of higher soil decomposition rates following the harvesting manipulation.

\section{Plant Responses in Post-EAB Black Ash Wetlands}

Early work evaluating plant response to EAB was associated with a post-invasion study in southeastern Michigan that included transects and stands across ash cover types with moisture regimes from xeric to mesic to hydric, with those hydric stands dominated by black ash $[9,27]$. The transects were established in 2004 and emanated up to $45 \mathrm{~km}$ from the epicenter of EAB invasion. In that study, black ash was equally susceptible as green ash (Fraxinus pennsylvanica Marsh.) and white ash (Fraxinus americana L.) to EAB invasion and subsequent mortality. However, the advancement of mortality and decline early in the invasion process was highest for black ash [9]. Smith et al. [9] postulated that the initial higher decline was a product of black ash being taxonomically most similar to Manchurian ash (Fraxinus mandshurica Rupr.), the species that EAB coevolved with in Asia. As a result, 
black ash has all the same cues for the female borer but none of the resistance, leading to higher initial decline rates. Across the same gradient of stands, all ash mortality was greater than $99 \%$ by 2009 (Figure 4; [27]).

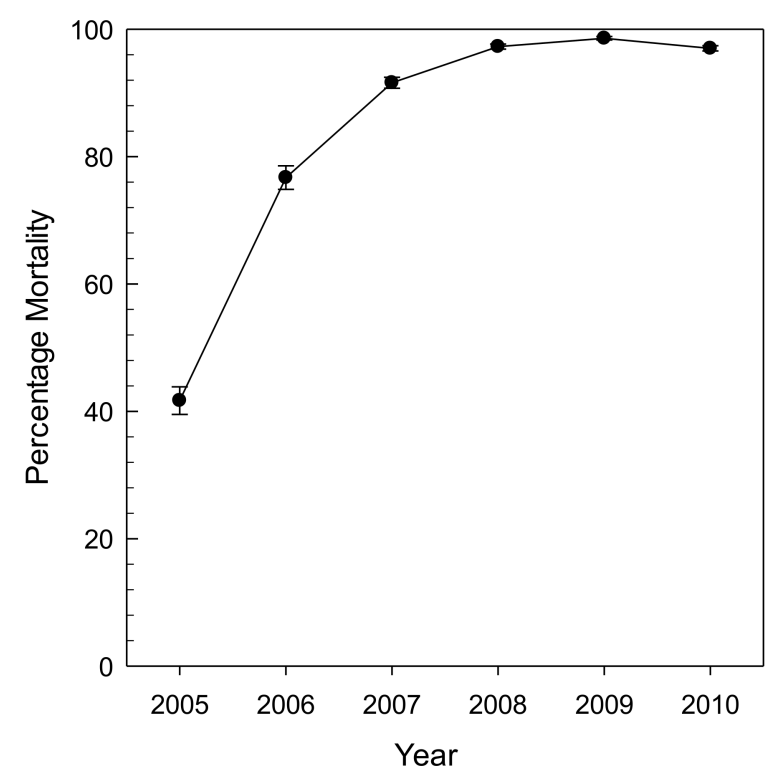

Figure 4. Percentage of ash mortality of trees $>2.5 \mathrm{~cm}$ at $1.37 \mathrm{~m}$ height in subplots and $>12.5 \mathrm{~cm}$ at $1.37 \mathrm{~m}$ height in main plots from 38 stands that included black, green, and white ash in the Huron River watershed in lower Michigan (reprinted with permission, [27]).

In the years shortly after EAB invasion in lower Michigan, and during the decline of black ash, there were numerous black ash seedlings and saplings in the understory, but by 2009 few to no ash seedlings germinated and the seed bank was barren of viable ash seeds [27,28]. The results from lower Michigan may be an ominous precursor of the fate of black ash across the western Great Lakes. As discussed above, the removal of black ash from the wetland canopy will lead to higher water tables and more inundation, possibly preventing the establishment of replacement canopy species. In upper Michigan, the ash-cut and girdled treatments did not lead to an increase in growth rates of the remaining canopy species that would be expected given the increase in resources (e.g., sunlight and nutrients) after canopy reduction [29]. The lack of response is presumably because of the water table dynamics discussed above. Although there were some small positive responses in non-ash sapling growth rates and a shift towards red maple and yellow birch in the seedling layer, the predominant response was a near doubling of the herbaceous species canopy area 2-3 growing seasons after the ash-cut and girdling treatments [29]. Moreover, Davis et al. [29] reported increased heights of the herbaceous layer, upwards of greater than $0.5 \mathrm{~m}$ post-treatment. The plant responses were most prominent in the obligate wetland plant species, again indicating that changes in water tables were affecting the plant community composition [29]. Studies in Minnesota indicated a similar increase in the height of the herbaceous cover in the clearcut, girdled, and group selection treatments, but not a difference in herbaceous cover [30]. A grass species (Calamagrostis canadensis (Michx.) Beauv.) was an indicator of the clearcut treatment, with a forb (Arisaema triphyllum (L.) Schott), fern (Matteuccia struthiopteris L. Tod), and sedge (Carex radiata (Wahlenb.)) indicators of the girdled treatment. However, unlike the upper Michigan study, Looney et al. [30] did not find an increase in obligate wetland herbaceous plants in the clearcut, girdled, or group selection treatments. In contrast to the lower Michigan studies, where an actual EAB invasion occurred and few to none of the black ash seedlings germinated about 7 years after invasion, in both upper Michigan and Minnesota black ash seedlings and saplings dominated in the woody component of the understory in the harvest treatments 2-3 years after the simulated EAB invasions. It appears time since invasion and the actual presence 
of $\mathrm{EAB}$ are important factors that will dictate the response of the vegetation community following EAB invasion.

A primary objective of the Minnesota study that was also adopted by the upper Michigan study was to investigate potential species to plant in advance of EAB to reduce vulnerability of black ash wetlands to EAB impacts (general trends summarized in Table 1: [10,31,32]). The upper Michigan investigation also included an associated study assessing alternative species establishment in green and black ash-dominated riparian areas near Superior, Wisconsin. In the Minnesota study, most of the 12 species planted had both fall and spring plantings. Across all treatments the species that had the highest rate of survival after three growing seasons were swamp white oak (Quercus bicolor Willd.), American elm, and the non-native Manchurian ash, all with greater than 70\% survival [10]. The species that had the poorest survival were native species, currently found in these forests, including yellow birch, trembling aspen (Populus tremuloides Michx.), and tamarack (Larix laricina (Du Roi) K. Koch), all with less than $10 \%$ survival. Although within individual species there were some small differences in survival rate depending on the season of planting, across all species there were no survival differences between fall and spring planting [10]. Similarly, there were differences in survival among species across treatments but overall the clearcut treatment had the lowest survival, and the girdled and group selection treatments had no differences when compared to the unharvested controls.

Table 1. Mean under planting survivability (\%) after three growing seasons from three planting studies in uninfested black ash wetlands. Minnesota results [10] are the mean values from the control stands and the Michigan and Wisconsin results [32] are from the hummock planting locations. NA is not applicable, as those species were not planted in the individual study.

\begin{tabular}{|c|c|c|c|c|}
\hline Common Name & Latin Name & Minnesota & Michigan & Wisconsin \\
\hline American elm & Ulmus americana & 93 & 68 & NA \\
\hline Swamp white oak & Quercus bicolor & 83 & NA & NA \\
\hline Hackberry & Celtis occidentalis & 77 & NA & 66 \\
\hline Silver maple & Acer saccharinum & NA & 76 & NA \\
\hline Manchurian ash & Fraxinus mandshurica & 74 & NA & NA \\
\hline Red maple & Acer rubrum & 33 & 11 & 68 \\
\hline Basswood & Tilia americana & NA & 64 & NA \\
\hline N. white cedar & Thuja occidentalis & 16 & 39 & 39 \\
\hline Bur oak & Quercus macrocarpa & NA & 38 & NA \\
\hline Balsam poplar & Populus balsamifera & 29 & NA & NA \\
\hline Black spruce & Picea mariana & 17 & 13 & NA \\
\hline Yellow birch & Betula alleghaniensis & 4 & 8 & NA \\
\hline Tamarack & Larix laricina & 8 & 0 & NA \\
\hline Balsam fir & Abies balsamea & NA & 7 & NA \\
\hline Eastern cottonwood & Populus deltoides & 5 & NA & NA \\
\hline Quaking aspen & Populus tremuloides & 0.3 & NA & NA \\
\hline
\end{tabular}

Further analysis of the growth rates of 10 of the 12 planted species in the Minnesota study indicated that the seedlings in the clearcut treatment had the greatest diameter growth and the seedlings in both the clearcut and girdled treatments had the greatest height growth [31]. Even though seedlings in the clearcut treatment had the lowest survival, those seedlings that did survive were growing at a faster rate than the survivors in the other treatments, likely because of increased light availability following cutting [31]. Within species and across treatments, balsam poplar (Populus balsamifera L.), eastern cottonwood (Populus deltoides W. Bartram ex Marshall), and tamarack tended to have the greatest height and diameter growth while Manchurian ash, black spruce (Picea mariana Mill. britton sterns \& poggenb), American elm, and common hackberry (Celtis occidentalis L.) tended to have the lowest growth rates [31]. Individual species growth rates do not necessarily coincide with survival rates, indicating seedling establishment is critical. Once established, species tolerance to light and hydrological conditions likely dictates growth rates. Contrary to the Minnesota study, upper Michigan seedling growth rates did somewhat track seedling survival rates, with the greatest height growth for American elm and silver maple, and least height growth for those species with the lowest survival [32]. 
The upper Michigan study and associated Wisconsin study focused on the effect of microsite conditions on seedling establishment. For the 10 species studied in upper Michigan, 8 species had greater survival on hummocks than in hollows and 5 of 7 species that had some survival in both locations also had greater height growth when planted on hummocks [32]. For the three species studied in Wisconsin, both hackberry and red maple tended to have greater survival on constructed hummocks, whereas northern white cedar tended to have the highest survival on unmanipulated planting sites. Overall, it is quite clear that microsites that are elevated above the water table have the greatest survival and growth rates, a result that is consistent with other studies in forested wetlands [33]. For the upper Michigan sites, silver maple (Acer saccharinum L.), American basswood (Tilia americana L.), and American elm all had greater than $40 \%$ survival rates after 3 years across microsites, while tamarack, red maple, yellow birch, balsam fir (Abies balsamea (L.) Mill.), and black spruce all had less than $10 \%$ survival [32]. Although the species selected across studies were anticipated to survive and grow in wet conditions, species such as American elm, hackberry, silver maple, and red maple are not obligate wetland species and yet they outperformed obligate species such as yellow birch and northern white cedar. Other factors such as the influence of microsite elevation appear to be critical when considering replacement species for black ash.

Across studies it appears that American elm and some more southerly distributed species did well, such as hackberry, swamp white oak, and eastern cottonwood in Minnesota, silver maple and bur oak (Quercus macrocarpa Michx.) in upper Michigan, and hackberry in Wisconsin. Modeling of black ash replacement species that considered climate change and migration of species indicated that both species that are currently present in black ash wetlands and are adapted to future climate (e.g., American elm, red maple, and American basswood) and species that do not currently co-occur with black ash but are not much further south (e.g., silver maple, eastern cottonwood, and hackberry) have great potential [34]. Although the modeling was focused on replacement species for black ash in Minnesota, the results also agree with the short-term field study results in both Wisconsin and upper Michigan. Based on early seedling survival and growth results, and modeling, the effects of climate change and associated changes in hardiness zones on canopy replacement species also should be considered when planting black ash wetlands.

\section{Animal Responses in Post-EAB Black Ash Wetlands}

Black ash wetlands provide important habitat for many wildlife species. The majority of black ash wetlands are uneven-aged stands [35], thus providing compositional and structural complexity that is important for wildlife. For example, young ash trees are a food source for deer and moose while mature trees provide nesting, roosting, or denning cavities for many bird and mammal species [36]. Despite the dominance of black ash wetlands on the landscape and the documented use of these forests by wildlife, minimal research has focused on the effects of EAB invasion on wildlife. Changes to hydrology and shifts in vegetation composition that occur after the die-back of black ash by EAB will impact wildlife, however, the magnitude and relative degree of impact to individual species and species diversity is unclear.

One of the only published studies on the impacts of EAB on wildlife focused on the indirect effects of EAB-induced mortality to ground beetle community assemblages (Coleoptera: Carabidae) in infected ash stands in Michigan [37]. The results of this study indicated that species diversity decreased in ash stands in response to tree mortality and increasing canopy gap size [37]. Hydric black ash wetlands had the most unique assemblage of ground beetles, with numerous beetle species only found in the hydric moisture category, but also had moderate turnover (25\%) of species from 2006-2007 [37]. Overall, the results indicated that beetle communities and diversity are susceptible to changes in environmental conditions caused by EAB invasion [37].

A comprehensive study is currently underway in Minnesota's black ash wetlands to investigate the potential effects of ash loss on bird, mammal, and herptile communities [36,38]. The reported environmental changes, such as an increase in ponding and tree mortality, that are known to occur 
in EAB infested stands will likely impact taxa and specific species in different ways. For example, many amphibians and invertebrates preferentially select open canopy wetlands because higher water temperatures and algal productivity result in rapid larval growth. Therefore, increases in ponding and longer hydroperiods may increase species richness and species abundance of pond-breeding amphibians and invertebrates because more species will be able use the wetlands for longer periods of time during the breeding season. Longer hydroperiods may also result in higher rates of juvenile recruitment for many amphibian species because individuals will be able to reach metamorphosis before pond drying occurs. Preliminary results from surveys of experimental black ash stands in Minnesota suggest that loss of ash could increase amphibian diversity and the biomass of some invertebrate taxa-namely, Coleoptera, Diptera, and Odonata [39]. However, certain functional feeding groups of macroinvertebrates may have lower abundance following EAB mortality because black ash litter provides a higher quality food resource than other tree species (reviewed in [40]).

Black ash wetlands provide a combination of structural complexity and high functional diversity of plants and invertebrates that are beneficial for many forest bird species. Black ash wetlands have diverse understory and complex canopy structure that provide unique micro-habitats that are beneficial for breeding birds. For example, structural features common in black ash stands such as large trees and coarse woody debris provide foraging opportunities, potential nest sites, and suitable singing perches for forest birds [41]. Preliminary data from Minnesota indicates that several bird species commonly associated with mature forests such as brown creeper (Certhia americana), northern parula (Setophaga americana), and winter wren (Troglodytes hiemalis) were common in black ash wetlands, however, species that require canopy openings such as chestnut-sided warbler (Setophaga pensylvanica) were also commonly observed [36]. These factors ultimately increased abundance, species richness, and species diversity in black ash wetlands compared to neighboring upland forests. Further, data from Minnesota suggests that black ash wetlands provide important stop-over habitat for migrating species including rusty blackbirds (Euphagus carolinus), which are one of North America's most rapidly declining bird species [42]. The transition of black ash wetlands to shrub- and sedge-dominated wetlands will result in the loss of important micro-habitats that are often limited across the forested landscape and may also reduce availability of critical habitat for migrating birds.

Recent changes in land use in the Great Lakes region has made loss of forest habitat and forest homogenization a growing threat to wildlife biodiversity [41,43]. Loss of forested wetlands across the landscape will likely intensify the impacts of current stressors such as climate change and habitat loss on wildlife populations [44,45]. For example, recent research suggests that diverse forests that contain an assortment of tree sizes may buffer the effects of warming temperatures for some wildlife species [46]. In Minnesota, preliminary results of camera trap surveys documented 12 mammal species, all of which, with the exception of ermine (Mustela erminea), were significantly more likely to use forested black ash stands compared to experimental EAB simulated stands (clearcuts) [36]. The difference in habitat use was particularly pronounced for forest-dependent species such as American marten (Martes americana) and fisher (Martes pennanti) [36]. These results suggest mammals are actively avoiding open areas; therefore, the conversion of forested wetlands to open wetlands will impact forest connectivity and exacerbate impacts of habitat loss for forest dependent species. Further, because habitat connectivity is one of the most important factors in maintaining biological diversity [47], the long-term impacts of EAB on wildlife diversity will likely be substantial.

Overall, the loss of black ash over small spatial scales may result in turnover of wildlife communities from forest dependent species to open-canopy and wetland associated species (e.g., forest bird species may be replaced with wetland associated species such as waterfowl). Although net changes in wildlife biodiversity may be minimal or potentially increase for some taxa (e.g., amphibians), the long-term, large-scale impacts of EAB on forest-associated wildlife will likely be significant [40]. Adaptive management strategies that focus on planting replacement tree species that maintain long-term compositional and structural complexity within these wetland systems will help maintain wildlife diversity. 


\section{What Do These Ecosystem Responses Mean for the Future of Black Ash Wetlands?}

The combined effects of the susceptibility of black ash to EAB, the current rate of spread of EAB, and warming conditions in the western Great Lakes, especially in the winter, will enhance the spread of EAB in the future [48]. It is likely that black ash wetlands will be highly impacted, reducing their abundance in the region. As water tables rise because of reduced black ash transpiration, we anticipate major changes in vegetation and associated animal communities. Concomitant changes in the amount and timing of precipitation could affect water table dynamics, but predictions for the region indicate higher annual precipitation in the future [49], potentially exacerbating the conversion of forests to non-forest conditions and resulting in more water available for runoff to streams or increases in water table elevations. While annual precipitation is predicted to increase in the future, the number of consecutive dry days (i.e., longer droughts) is also predicted to increase over much of the western Great Lakes. Although precipitation and drought patterns are very uncertain, possible increases in drought length and frequency may enhance the establishment of less water-tolerant non-ash tree species in former black ash wetlands.

Removing black ash from the wetland ecosystem may lower $\mathrm{N}$ inputs, which will likely have important consequences for plant growth and composition, microbial dynamics, decomposition, carbon sequestration, and other essential ecosystem functions. Ultimately, those changes in $\mathrm{N}$ will affect the lowest trophic levels of the animal community, with the potential to cascade up the food chain $[24,44,45]$.

Black ash wetlands are long-term sinks for $C$ based on the relatively high $C$ present in the soil, both in mineral and organic soil wetlands. Disruption of the hydrology and plant community by EAB will likely change short- and long-term $C$ dynamics. In mineral soil wetlands, the forest comprises a much larger fraction of the total ecosystem $C$ than in organic soil wetlands [50]. We hypothesize that if black ash wetlands convert to shrub or grass/sedge wetlands because of higher water tables following EAB invasion, both mineral and organic soil wetlands will likely be short-term sources of $\mathrm{C}$ as fresh downed-wood decomposes, releasing $\mathrm{CO}_{2}$ to the atmosphere. Higher water tables created by decreases in evapotranspiration following the loss of black ash after EAB invasion would also lead to a short-term increase in $\mathrm{CH}_{4}$ emissions shortly after $\mathrm{EAB}$ invasion. Longer term, the high water tables would be expected to lead to slower litter and soil decomposition and stabilization of $\mathrm{CH}_{4}$ emissions, lower emissions of $\mathrm{CO}_{2}$, and an overall ecosystem sink for $\mathrm{C}$, mainly through accumulation in the soil C pool.

\section{Needs for Future Research}

It is apparent from the paucity of research on black ash wetlands that we are only beginning to understand the dynamics of this ecosystem and specifically the ecological impacts post-EAB. Immediate research is needed to assess the impacts of EAB on native plant and animal biodiversity, ecosystem functions related to nutrient and C cycling, and hydrology, as well as to evaluate possible mitigation strategies for increasing the resilience of these imperiled ecosystems to EAB. Although we have some data on transpiration, no evaporation or groundwater flow data exist to close the water budget. A better understanding of the water budget will help us predict the possible conversion to non-forest conditions. While we have good evidence that removing all or most of the canopy will raise water tables, we have indications that canopy mortality of $20 \%$ or less can moderate water table impacts. There is a need to measure water tables and other components of the water budget across a range of canopy removal percentages to ascertain the level of mortality that causes significant changes in hydrologic regime. If that number, for example, is $40 \%$ of the canopy basal area, then those wetlands with less than $40 \%$ of the canopy in black ash would be more resilient to hydrologic changes following EAB infestation.

Other critical information gaps related to hydrologic response of black ash wetlands following EAB exist. Notably, the relative importance of water budget components to changes in hydrologic regime across black ash wetland hydrogeomorphic settings remains unknown. Different 
hydrogeomorphic settings likely have different mechanisms and alternative outcomes are possible. For example, the depth to confining layer is thought to be an important variable influencing response in perched systems [51], but the threshold depth where the hydrologic regime shifts is unknown. For depressional and swale settings, contributing area is likely a primary controlling factor and it may be that at certain scales (small or large) the effect of reduced black ash transpiration, because of loss of ash, on water table dynamics will be negligible. The lack of understanding of how black ash interacts with hydrology demonstrates the need for studies across the range of hydrogeomorphic settings that black ash encompasses. Ultimately, a greater understanding of hydrologic response over time is needed to assess the potential for ecosystem recovery. Data from the Minnesota sites indicates limited hydrologic recovery for at least five years after disturbance [51], but the longer-term response is unclear.

In addition to more detailed information on hydrologic regimes, we need better insight on how the replacement by herbaceous- or shrub-dominated vegetation will impact short- and long-term nutrient $\left(\mathrm{N}, \mathrm{P}\right.$, and cations) and carbon cycles. If former black ash wetlands become sources of $\mathrm{CO}_{2}$ and $\mathrm{CH}_{4}$ to the atmosphere, or even if there is a decrease in long-term storage capacity, conversion to other wetland types could have important feedbacks to our global climate. Moreover, developing restoration strategies to recover tree cover in these areas to offset these impacts is a critical need.

Other than the ground beetle study that occurred in black ash wetlands long after EAB infestation, we have no published data on animal responses. Black ash wetlands are critical habitats for invertebrates and amphibians as well as the species at higher trophic levels that depend on those communities (e.g., reptiles, birds, and mammals) [24]. We need studies that assess the response of these animal communities to $\mathrm{EAB}$ invasion to both develop an understanding of the temporal animal responses and create management approaches that consider effects on both floral and faunal communities. This assessment could be done using the simulated infestation sites or a chronosequence of pre- and post-infested black ash stands.

Given the ongoing spread of EAB into regions where black ash often dominate wetland forests, the need for additional research into the effects of $\mathrm{EAB}$ on ecosystems is urgent. As reviewed above, there have been great developments in our understanding of black ash wetlands in the past ten years, particularly with respect to how EAB will affect these forests and some of the subsequent physical and ecological changes that will follow infestation. Assessing the impacts of the loss of black ash on biota is the strongest outstanding need. We also still lack information on how infestation will alter physical and ecological processes across the range of black ash systems. Research to address these fundamental needs and existing mitigation strategies is currently underway and should provide critical information for further refinement of mitigation and management strategies.

Acknowledgments: The authors would like to thank Wendy Klooster for providing Figure 4, as well as all the students at the Michigan Technological University, the University of Minnesota, and Virginia Polytechnic Institute and State University.

Author Contributions: R.K. led the development of this synthesis and A.D., J.W., R.S., T.P, M.Y., A.G. and B.P. contributed to the writing of the paper.

Conflicts of Interest: The authors declare no conflict of interest.

\section{References}

1. Herms, D.A.; McCullough, D.G. Emerald ash borer invasion of North America: history, biology, ecology, impacts, and management. Ann. Rev. Entomol. 2014, 59, 13-30. [CrossRef] [PubMed]

2. USDA. Forest Service Forest Inventory and Analysis Program. Available online: https://apps.fs.usda.gov/ DATIM/Default.aspx (accessed on 13 November 2017).

3. Palik, B.J.; Ostry, M.E.; Venette, R.C.; Abdela, E. Fraxinus nigra (black ash) dieback in Minnesota: Regional variation and potential contributing factors. For. Ecol. Manag. 2011, 261, 128-135. [CrossRef]

4. Palik, B.J.; Ostry, M.E.; Venette, R.C.; Abdela, E. Tree regeneration in black ash (Fraxinus nigra) stands exhibiting crown dieback in Minnesota. For. Ecol. Manag. 2012, 269, 26-30. [CrossRef] 
5. Minnesota Department of Natural Resources. Native Plant Communities for Northern Very Wet Ash Swamp. 2018. Available online: http:/ / files.dnr.state.mn.us/natural_resources/npc/wet_forest/wfn64.pdf (accessed on 30 March 2018).

6. Lenhart, C.; Brooks, K.; Davidson, M.; Slesak, R.; D'Amato, A. Hydrologic source characterization of black ash wetlands: Implications for EAB response. In Riparian Ecosystems IV: Advancing Science, Economics and Policy, Proceedings of the American Water Resources Association Summer Specialty Conference, Denver, CO, USA, 27-29 June 2012; American Water Resources Association (AWRA): Middelburg, VA, USA, 2012.

7. Van Grinsven, M.J.; Shannon, J.P.; Davis, J.C.; Bolton, N.W.; Wagenbrenner, J.W.; Kolka, R.K.; Pypker, T.G. Source water contributions and hydrologic responses to simulated emerald ash borer infestations in depressional black ash wetlands. Ecohydrology 2017. [CrossRef]

8. Slesak, R.A.; Lenhart, C.F.; Brooks, K.N.; D'Amato, A.W.; Palik, B.J. Water table response to harvesting and simulated emerald ash borer mortality in black ash wetlands in Minnesota, USA. Can. J. For. Res. 2014, 44, 961-968. [CrossRef]

9. Smith, A.; Herms, D.A.; Long, R.P.; Gandhi, K.J.K. Community composition and structure had no effect on forest susceptibility to invasion by the emerald ash borer (Coleoptera: Buprestidae). Can. Entomol. 2015, 147, 318-328. [CrossRef]

10. Looney, C.E.; D'Amato, A.W.; Palik, B.J.; Slesak, R. Overstory treatment and planting season affect survival of replacement tree species in emerald ash borer threatened Fraxinus nigra forests in Minnesota, USA. Can. J. For. Res. 2015, 45, 1728-1738. [CrossRef]

11. Little, L., Jr. Checklist of United States Trees (Native and Naturalized); Agricultural Handbook 541; U.S. Department of Agriculture: Washington, DC, USA, 1979; 375p.

12. USDA Cooperative Emerald Ash Borer Project. Available online: http://www.emeraldashborer.info/ documents/MultiState_EABpos.pdf (accessed on 26 March 2018).

13. Telander, A.C.; Slesak, R.A.; D'Amato, A.W.; Palik, B.J.; Brooks, K.N.; Lenhart, C.F. Sap flow of black ash in wetland forests of northern Minnesota, USA: Hydrologic implications of tree mortality due to emerald ash borer. Agric. For. Meteorol. 2015, 206, 4-11. [CrossRef]

14. Shannon, J.; van Grinsven, M.; Davis, J.; Bolton, N.; Noh, N.J.; Wagenbrenner, J.; Pypker, T.; Kolka, R. Water level controls on sap flux of canopy species in black ash (Fraxinus nigra) wetlands. Forests 2018, 9, 147. [CrossRef]

15. Stednick, J.D. Monitoring the effects of timber harvest on annual water yield. J. Hydrol. 1996, 176, 79-95. [CrossRef]

16. Ferrari, J. Fine-scale patterns of leaf litterfall and nitrogen cycling in an old-growth forest. Can. J. For. Res. 1999, 29, 291-302. [CrossRef]

17. Pastor, J.; Post, W.M. Influence of climate, soil moisture, and succession on forest carbon and nitrogen cycles. Biogeochemistry 1986, 2, 3-27. [CrossRef]

18. Slesak, R.A. (Minnesota Forest Resources Council, St. Paul, MN, USA). Unpublished data, 2015.

19. Kolka, R.K. (USDA Forest Service Northern Research Station, Grand Rapids, MN, USA). Unpublished data, 2016.

20. Davis, J. Vegetation Dynamics and Nitrogen Cycling Responses to Simulated Emerald Ash Borer Infestation in Fraxinus Nigra-dominated Wetlands of Upper Michigan, USA. Ph.D. Thesis, Michigan Technological University, School of Forest Resources and Environmental Science, Houghton, MI, USA, 17 November 2016.

21. Langenbruch, C.; Helfrich, M.; Flessa, H. Effects of beech (Fagus sylvatica), ash (Fraxinus excelsior) and lime (Tilia spec.) on soil chemical properties in a mixed deciduous forest. Plant. Soil 2012, 352, 389-403. [CrossRef]

22. Vesterdal, L.; Schmidt, I.; Callesen, I.; Nilsson, L.; Gundersen, P. Carbon and nitrogen in forest floor and mineral soil under six common European tree species. For. Ecol. Manag. 2008, 255, 35-48. [CrossRef]

23. Nisbet, D.; Kreutzweiser, D.; Sibley, P.; Scarr, T. Ecological risks posed by emerald ash borer to riparian forest habitats: A review and problem formulation with management implications. For. Ecol. Manag. 2015, 358, 165-173. [CrossRef]

24. Palik, B.J.; Batzer, D.P.; Kern, C. Upland forest linkages to seasonal wetlands: Litter flux, processing, and food quality. Ecosystems 2005, 8, 1-11. [CrossRef]

25. Van Grinsven, M.J.; Shannon, J.P.; Bolton, N.W.; Davis, J.C.; Noh, N.J.; Wagenbrenner, J.W.; Kolka, R.K.; Pypker, T.G. Response of Black Ash Wetland Gaseous Soil Carbon Fluxes to a Simulated Emerald Ash Borer Disturbance. Forests, 2018, in review. 
26. Van Grinsven, M.J.; Shannon, J.P.; Noh, N.J.; Kane, E.S.; Bolton, N.W.; Davis, J.C.; Wagenbrenner, J.W.; Sebestyen, S.D.; Kolka, R.K.; Pypker, T.G. Stream Water, Total Nitrogen and Carbon Load Responses to a Simulated Emerald Ash Borer Infestation in Black Ash Dominated Headwater Wetlands. In Proceedings of the American Geophysical Union Annual Conference, New Orleans, LA, USA, 11-15 December 2017.

27. Klooster, W.S.; Herms, D.A.; Knight, K.S.; Herms, C.P.; McCullough, D.G.; Smith, A.; Gandhi, K.J.K.; Cardina, J. Ash (Fraxinus spp.) mortality, regeneration, and seed bank dynamics in mixed hardwood forests following invasion by emerald ash borer (Agrilus planipennis). Biol. Invasions 2014, 16, 859-873. [CrossRef]

28. Kashian, D.M.; Witter, J.A. Assessing the potential for ash canopy tree replacement via current regeneration following emerald ash borer-caused mortality on southeastern Michigan landscapes. For. Ecol. Manag. 2011, 261, 480-488. [CrossRef]

29. Davis, J.C.; Shannon, J.P.; Bolton, N.W.; Kolka, R.K.; Pypker, T.G. Vegetation responses to simulated emerald ash borer infestation in Fraxinus nigra dominated wetlands of Upper Michigan, USA. Can. J. For. Res. 2017, 47, 319-330. [CrossRef]

30. Looney, C.E.; D'Amato, A.W.; Palik, B.J.; Slesak, R.A.; Slater, M.A. The response of Fraxinus nigra forest ground-layer vegetation to emulated emerald ash borer mortality and management strategies in northern Minnesota, USA. For. Ecol. Manag. 2017, 389, 352-363. [CrossRef]

31. Looney, C.E.; D'Amato, A.W.; Palik, B.J.; Slesak, R. Canopy treatment influences growth of replacement tree species in Fraxinus nigra forests threatened by emerald ash borer in Minnesota, USA. Can. J. For. Res. 2017, 47, 183-192. [CrossRef]

32. Bolton, N.; Shannon, J.; Davis, J.; van Grinsven, M.; Noh, N.J.; Schooler, S.; Kolka, R.; Pypker, T.; Wagenbrenner, J. Methods to improve alternative species seedlings survival and growth in black ash ecosystems threatened by emerald ash borer. Forests 2018, 9, 146. [CrossRef]

33. Palik, B.; Haworth, B.K.; David, A.J.; Kolka, R.K. Survival and growth of northern white-cedar and balsam fir seedlings in riparian management zones in northern Minnesota, USA. For. Ecol. Manag. 2015, 337, $20-27$. [CrossRef]

34. Iverson, L.; Knight, K.S.; Prasad, A.; Herms, D.A.; Matthews, S.; Peters, M.; Smith, A.; Hartzler, D.M.; Long, R.; Almendinger, J. Potential species replacements for black ash (Fraxinus nigra) at the confluence of two threats: Emerald ash borer and a changing climate. Ecosystems 2016, 19, 248-270. [CrossRef]

35. Erdmann, G.G.; Crow, T.R.; Peterson, R.M.; Wilson, C.D. Managing Black Ash in the Lake States; General Technical Report NC-115; U.S. Department of Agriculture, Forest Service, North Central Forest Experiment Station: St. Paul, MN, USA, 1987.

36. Grinde, A.R.; (University of Minnesota Duluth, Duluth, MN, USA). Unpublished data, 2017.

37. Gandhi, K.J.K.; Smith, A.; Hartzler, D.M.; Herms, D.A. Indirect effects of emerald ash borer-induced ash mortality and canopy gap formation on epigaeic beetles. Environmental Entomology 2014, 43, 546-555. [CrossRef] [PubMed]

38. Youngquist, M.B.; (University of Minnesota, St. Paul, MN, USA). Unpublished data, 2017.

39. Youngquist, M.B.; (University of Minnesota, St. Paul, MN, USA). Unpublished data, 2016.

40. Youngquist, M.B.; Eggert, S.L.; D'Amato, A.W.; Palik, B.J.; Slesak, R.A. Potential effects of foundation species loss on wetland communities: A case study of black ash wetlands threatened by emerald ash borer. Wetlands 2017, 37, 787-799. [CrossRef]

41. Niemi, G.J.; Howe, R.W.; Sturtevant, B.R.; Parker, L.R.; Grinde, A.R.; Danz, N.P.; Nelson, M.D.; Zlonis, E.J.; Walton, N.G.; Gnass Giese, E.E.; et al. Analysis of Long Term Forest Bird Monitoring from National Forests of the Western Great Lakes Region; General Technical Report NRS-159; U.S. Department of Agriculture, Forest Service, Northern Research Station: Newtown Square, PA, USA, 2016.

42. Sauer, J.R.; Niven, D.K.; Hines, J.E.; Ziolkowski, D.J., Jr.; Pardieck, K.L.; Fallon, J.E.; Link, W.A. The North. American Breeding Bird Survey, Results and Analysis 1966-2015; Version 2.07.2017; USGS Patuxent Wildlife Research Center: Laurel, MD, USA, 2017.

43. Schulte, L.A.; Mladenoff, D.J.; Crow, T.R.; Merrick, L.C.; Cleland, D.T. Homogenization of northern US Great Lakes forests due to land use. Landsc. Ecol. 2007, 22, 1089-1103. [CrossRef]

44. Grinde, A.R.; Niemi, G.J. A synthesis of species interactions, metacommunities, and the conservation of avian diversity in hemiboreal and boreal forests. J. Avian Biol. 2016, 47, 706-718. [CrossRef] 
45. Grinde, A.R.; Niemi, G.J.; Sturtevant, B.R.; Panci, H.; Thogmartin, W.; Wolter, P. Importance of scale, land cover, and weather on the abundance of bird species in a managed forest. For. Ecol. Manag. 2017, 405, 295-308. [CrossRef]

46. Betts, M.G.; Phalan, B.; Frey, S.J.K.; Rousseau, J.S.; Yang, Z. Old-growth forests buffer climate-sensitive bird populations from warming. Divers. Distrib. 2018, 24, 439-447. [CrossRef]

47. Correa Ayram, C.A.; Mendoza, M.E.; Etter, A.; Salicrup, D.R.P. Habitat connectivity in biodiversity conservation: A review of recent studies and applications. Prog. Phys. Geogr. 2016, 40, 7-37. [CrossRef]

48. Climate Central. Researching and Reporting the Science and Impacts of Climate Change. Available online: http:/ / www.climatecentral.org/gallery/maps/heres-where-winters-are-warming-the-most (accessed on 30 March 2018).

49. Pryor, S.C.; Scavia, D.; Downer, C.; Gaden, M.; Iverson, L.; Nordstrom, R.; Patz, J.; Robertson, G.P. Chapter 18: Midwest. In Climate Change Impacts in the United States: The Third National Climate Assessment; Melillo, J.M., Richmond, T.C., Yohe, G.W., Eds.; U.S. Global Change Research Program: Washingtion, DC, USA, 2014; pp. 418-440.

50. Bridgham, S.D.; Megonigal, J.P.; Keller, J.K.; Bliss, N.B.; Trettin, C. The carbon balance of North American wetlands. Wetlands 2006, 26, 889-916. [CrossRef]

51. Diamond, J.S.; McLaughlin, D.; Slesak, R.A.; D'Amato, T.D.; Palik, B.J. Ecohydrologic response of black ash wetlands to emerald ash borer infestation and potential mitigation strategies. Ecol. Appl. 2018, in press.

(C) 2018 by the authors. Licensee MDPI, Basel, Switzerland. This article is an open access article distributed under the terms and conditions of the Creative Commons Attribution (CC BY) license (http://creativecommons.org/licenses/by/4.0/). 